\title{
Pengaruh Kemiskinan, Tingkat Pengangguran, Pertumbuhan Ekonomi dan Pengeluaran Pemerintah Terhadap Indeks Pembangunan Manusia (IPM) di Indonesia Tahun 2014-2018 dalam Perspektif Islam
}

\author{
Jahtu Widya Ningrum ${ }^{1}$, Aziza Hanifa Khairunnisa ${ }^{2}$, Nurul Huda ${ }^{3}$ \\ ${ }^{1,2}$ Mahasiswa S2 Program Studi Kajian Timur Tengah dan Islam, Universitas Indonesia \\ ${ }^{3}$ Universitas Yarsi \\ * Email Korespondensi : nurul.huda@yarsi.ac.id
}

\begin{abstract}
This study aims to determine the effect of poverty, unemployment, economic growth and government spending on the Human Development Index (HDI) in Indonesia in 2014-2018 in an Islamic perspective. Data processing in this study uses descriptive analysis and panel data regression analysis with a pool model approach using Eviews 9 software using secondary data obtained from data that has been published in several sources, Badan Pusat Statistika and the Kementrian Keuangan website for the period of 2014 to 2018. The results of this study indicate that partially the poverty variable and the unemployment rate have a significant effect on HDI which is indicated by a probability value smaller than alpha (0.05), while the economic growth and government expenditure variables have no significant effect on the HDI indicated by the probability value of more greater than the alpha value (0.05). Simultaneously all the research variables have a significant effect on HDI and have an effect that is shown through $R 2$ of $80.78 \%$ indicating that the variables of poverty, unemployment rate, economic growth, government expenditure can explain the $Y$ variable, the remaining $19.22 \%$ is explained by other variables outside the research variable.
\end{abstract}

Keyword: poverty, unemployment rate, economic growth, and Human Development Index.

Saran sitasi: Gultom, R. Z., \& Tini, A. Q., (2020). Pengaruh Kemiskinan, Tingkat Pengangguran, Pertumbuhan Ekonomi dan Pengeluaran Pemerintah Terhadap Indeks Pembangunan Manusia (IPM) di Indonesia Tahun 2014-2018 dalam Perspektif Islam. Jurnal Ilmiah Ekonomi Islam, 6(02), 212-222. doi:http://dx.doi.org/10.29040/jiei.v6i2.1034

DOI: http://dx.doi.org/10.29040/jiei.v6i2.1034

\section{PENDAHULUAN}

Kehidupan yang sejahtera merupakan kehidupan yang diinginkan oleh semua manusia. Akan tetapi, tidak semua orang dapat merasakan hidup secara sejahtera. Menurut Al-Ghazali dalam Huda (2012) kesejahteraan manusia terletak pada perlindungan keimanan (dīn), jiwa (nafs), akal (aqal), keturunan (nasb) dan kekayaan (mal). Islam mengajarkan untuk tidak meninggalkan keturunan dalam keadaan lemah baik secara ekonomi, agama, ilmu maupun pertahanan.

Salah satu cara yang dapat dilakukan suatu negara untuk meningkatkan kesejahteraan rakyatnya adalah dengan melakukan pembangunan, salah satunya pada bidang ekonomi, dimana pertumbuhan ekonomi menjadi indikatornya. Menurut Adam Smith dalam Prihastuti (2018) sumber daya manusia merupakan input yang berperan penting dalam pembangunan ekonomi, dimana pembangunan ini merupakan penyebab kesejahteraan suatu negara, yaitu pentingnya skala ekonomi dan juga kualitas manusia itu sendiri.

Salah satu indikator yang dapat dilihat untuk mengukur kualitas manusia dan skala ekonomi adalah Indeks Pembangunan Manusia (IPM). IPM merupakan salah satu indikator yang dapat digunakan untuk mengukur tingkat keberhasilan pembangunan kualitas manusia. IPM pertama kali diperkenalkan oleh United Nations Development Programme (UNDP) pada tahun 1990. Badan Pusat Statistik (BPS) telah merubah beberapa indikator dari IPM yang sudah tidak relevan untuk digunakan dalam perhitungan IPM, yaitu Angka Melek Huruf yang diubah menjadi Angka Harapan Lama Sekolah, lalu 
Produk Domestik Bruto (PDB) per kapita yang diubah menjadi Produk Nasional Bruto (PNB) per kapita. Selain itu, kemiskinan diduga dapat menjadi disparitas dalam meningkatkan Indeks Pembangunan Manusia. Hal ini karena kemiskinan dapat menghambat seseorang untuk mendapatkan tingkat pendidikan yang layak, dan tingkat kesehatan yang layak dapat menyebabkan tidak ada peningkatan pada sumber daya manusia dan dapat menyebabkan pengangguran meningkat.

Indeks Pembangunan Manusia di Indonesia masih tergolong rendah dibandingkan dengan negaranegara lain di dunia. Menurut data dari Badan Pusat Statistika (2018), terdapat perlambatan pertumbuhan Indeks Pembangunan Manusia (IPM) pada periode 2016-2018 dibanding tahun-tahun sebelumnya meskipun secara nominal tetap tumbuh secara positif. Pada periode 2015-2018, IPM Nasional tumbuh berturut-turut sebesar $0.93 \%, 0.91 \%, 0.90 \%$, dan $0.82 \%$.

Menurut Christy dan Adi (2009), Indeks Pembangunan Manusia juga dipengaruhi oleh faktorfaktor lain, seperti ketersediaan kesempatan kerja, yang selanjutnya ditentukan oleh banyak faktor terutama pertumbuhan ekonomi, infrastuktur dan kebijakan pemerintah. Infrastuktur dibangun oleh negara melalui belanja modal. Dalam Peraturan Menteri Keuangan Nomor 101/PMK.02/2011 belanja modal dapat berupa: tanah, peralatan dan mesin, gedung dan bangunan, jalan, irigasi dan jaringan, belanja modal lainnya, dan belanja modal Badan Layanan Umum (BLU).

Selain itu, untuk meningkatkan kualitas sumber daya manusia, pemerintah sebagai agen pelaksana pembangunan nasional tentu membutuhkan modal sebagai dasar pembangunan. Pemerintah melakukan pengeluaran atau investasi yang ditujukan untuk pembangunan manusia. Pengeluaran pemerintah merupakan cerminan kebijakan yang diambil oleh pemerintah. Dalam hal ini pengeluaran pemerintah tersebut digunakan untuk membiayai sektor publik yang lebih penting dan menjadi prioritas dalam peningkatan kualitas sumber daya manusia yang tercermin pada Indeks Pembangunan Manusia (IPM) (Baeti, 2013).

Berdasarkan paparan latar belakang diatas, maka tujuan dari penelitian ini adalah untuk mengetahui dan juga menganalisis apakah Kemiskinan, Tingkat Pengangguran, Pertumbuhan Ekonomi, dan Pengeluaran Pemerintah memiliki pengaruh terhadap
Indeks Pembangunan Manusis (IPM) yang selanjutnya hasil dari penelitian dilihat dari perspektif Islam.

\section{Indeks Pembangunan Manusia}

IPM digunakan untuk mengukur sejauh mana keberhasilan kualitas hidup manusia dan) berfungsi untuk mengukur capaian pembangunan manusia berbasis sejumlah komponen dasar kualitas hidup. Sebagai ukuran kualitas hidup, IPM dibangun melalui pendekatan tiga dimensi dasar. yaitu umur panjang dan hidup sehat, pengetahuan, serta standar hidup layak. Setiap dimensi diwakili oleh indikator. Dimensi umur panjang dan hidup sehat diwakili oleh indikator umur harapan hidup saat lahir. Sementara itu, rata-rata lama sekolah dan harapan lama sekolah merupakan indikator yang mewakili dimensi pengetahuan. Terakhir, dimensi standar hidup layak Indonesia diwakili oleh indikator pengeluaran per kapita yang disesuaikan. (BPS, Indeks Pembangunan Manusia 2018, 2018).

Rumus yang digunakan dalam menghitung Indeks Pembangunan Manusia adalah sebagai berikut:

$$
\text { IPM }=\frac{1}{3}(\text { Indeks X1+Indeks X2+Indeks X3) }
$$

Dimana :

X1 : lamanya hidup

$\mathrm{X} 2$ : tingkat pendidikan

X3 : standar hidup layak yang menggunakan indikator kemampuan daya beli.

Terdapat 3 golongan status pembangunan manusia berdasarkan nilai IPM yaitu: (1) IPM $<50$ dikatakan rendah, (2) $50 \leq$ IPM $<80$ dikatakan sedang/menengah, dan (3) IPM $\geq 80$ dikatakan tinggi.

\section{Kemiskinan}

Chamber dalam Prasetyo (2010) kemiskinan merupakan keadaan dimana seseorang mengalami kekurangan uang dan barang untuk menjamin kelangsungan hidup. Dalam arti luas, kemiskinan merupakan suatu integrate concept yang memiliki lima dimensi, yaitu : 1) Kemiskinan, 2) ketidakberdayaan 3) kerentanna menghadapi situasi darurat, 4) ketergantungan, dan 5) keterasingan baik secara geografis maupun sosiologis. Selanjutnya, Amartya Send dalam Suradi (2007) mengungkapkan bahwa terdapat inti absolut dari kemiskinan. Kelaparan yang melanda mereka menjadi sebuah perspektif dari kemiskinan, demikian juga dengan ketidakmampuan dalam kehinaan sosial dan ketidakmampuan dalam mendidik anak-anak (pendidikan) serta merawat kesehatan anak-anak 
Garis kemiskinan absolut sangat penting untuk menilai efek dari kebijakan anti kemiskinan antar waktu, atau memperkirakan dampak dari suatu proyek terhadap kemiskinan (misalnya, pemberian kredit skala kecil). Angka kemiskinan akan terbanding antara satu negara dengan negara lain hanya jika garis kemiskinan absolute yang sama digunakan di kedua negara tersebut. Bank Dunia memerlukan garis kemiskinan absolut agar dapat membandingkan angka kemiskinan antar negara. Hal ini bermanfaat dalam menentukan kemana menyalurkan sumber daya finansial (dana) yang ada, juga dalam menganalisis kemajuan dalam memerangi kemiskinan. Pada umumnya, terdapat dua ukuran yang digunakan oleh Bank Dunia dalam mengukur kemiskinan, yaitu : a.) US \$ 1 perkapita per hari dimana diperkirakan ada sekitar 1,2 miliar penduduk dunia yang hidup dibawah ukuran tersebut; b) US \$ 2 perkapita per hari dimana lebih dari 2 miliar penduduk yang hidup kurang dari batas tersebut. US dollar yang digunakan adalah US \$ PPP (Purchasing Power Parity), bukan nilai tukar resmi (exchange rate). Kedua batas ini merupakan garis kemiskinan absolut (BPS, 2018).

\section{Tingkat Pengangguran}

Pengangguran adalah masalah makroekonomi yang mempengaruhi manusia secara langsung dan merupakan yang paling berat. Bagi kebanyakan orang, kehilangan pekerjaan berarti penurunan standar kehidupan dan tekanan psikologis (Mankiw, 2003). Menurut Sukirno dalam Meydiasari dan Soejoto (2017) pengangguran adalah seseorang yang sudah digolongkan dalam angkatan kerja, yang secara aktif sedang mencari pekerjaan pada suatu tingkat upah tertentu, tetepi belum meperoleh pekerjaan yang diinginkannya. Selain itu, Sukirno (2000) juga mengklasifikasikan pengangguran berdasarkan cirinya, yang dibagi menjadi: 1) pengangguran terbuka, 2) pengangguran tersembunyai, 3) setengah menganggur, dan 4) pengangguran bermusim. Lebih spesifik, pada penelitian ini, jenis pengangguran yang akan digunakan pada penelitiaan ini adalah pengangguran terbuka. Pengangguran terbuka dapat berarti angkatan kerja yang belum bekerja dan sedang aktif mencari pekerjaan (Masriah \& Mujahid, 2011). Tingkat pengangguran terbuka dapat dihitung sebagai berikut:

$\mathrm{TPT}=\frac{\text { Jumlah Pengangguran }}{\text { Jum angkatan } \text { ker ja }} \times 100 \% \ldots \ldots$.

\section{Pertumbuhan Ekonomi}

Menurut Sukirno (1996) dalam Prihastuti (2018) pertumbuhan ekonomi adalah proses kenaikan output perkapita yang terus menerus dalam jangka waktu yang panjang dan merupakan salah satu indikator keberhasilan pembangunan, makin tingginya pertumbuhan ekonomi biasanya makin tinggi pula kesejahteraan masyarakat. Todaro dalam Sasana (2009) menyampaikan ada tiga faktor atau komponen utama dalam pertumbuhan ekonomi dari setiap negara. Ketiga faktor tersebut adalah:

1. Akumulasi modal, yang meliputi semua bentuk atau jenis investasi baru yang ditanamkan pada tanah, peralatan fisik, dan modal atau sumber daya manusia.

2. Pertumbuhan penduduk, yang pada akhirnya akan memperbanyak jumlah angkatan kerja.

3. Kemajuan teknologi, berupa cara baru atau perbaikan cara-cara lama dalam menangani pekerjaan-pekerjaan.

Rumus pertumbuhan ekonomi adalah sebagai berikut: Pertumbuhan $=\frac{P D R B t-P D R B t-}{P D R B t-1} \times 100 \% \ldots$.

\section{Pengeluaran Pemerintah}

\section{Mangkoesoebroto}

menyebutkan

teori pengeluaran pemerintah secara makro dikemukakan oleh tiga ahli ekonomi yang berbeda yaitu Rostow dan Musgrave, Adolf Wegner, dan Peacock dan Wiseman. Rostow dan Musgrave menghubungkan perkembangan pengeluaran pemerintah dengan tahap-tahap pembangunan ekonomi yaitu tahap awal, tahap menengah dan tahap lanjut. Perkembangan pengeluaran pemerintah oleh Adolf Wagner menjelaskan bahwa semakin meningkatnya pendapatan per kapita dalam suatu perekonomian maka secara relatif pengeluaran pemerintah akan meningkat. Sehingga kurva peningkatan pengeluaran pemerintah berbentuk eksponensial. Hukum Wagner yang terkenal yaitu "The Law of Expanding State Expenditure" dimana pengeluaran pemerintah terus meningkat disebabkan oleh peranan pemerintah yang semakin besar dalam mengurus segala aktivitas yang berhubungan dengan masyarakat, hukum, pendidikan, rekreasi dan kebudayaan. (Vildzah \& Muhammad, 2016).

Pengeluaran pemerintah adalah nilai pembelanjaan yang dilakukan oleh pemerintah yang digunakan untuk kepentingan masyarakat. Pengeluaran pemerintah mencerminkan kebijakan pemerintah. Apabila pemerintah telah menetapkan 
suatu kebijakan untuk membeli barang dan jasa, pengeluaran pemerintah mencerminkan biaya yang harus dikeluarkan oleh pemerintah untuk melaksanakan kebijakan tersebut (Mangkoesoebroto, 1993).

\section{Penelitian Terdahulu}

Penelitian pertama dilakukan oleh Denni Sulistio Mirza (2012) yang meneliti mengenai hubungan dan pengaruh kemiskinan, pertumbuhan ekonomi, dan belanja modal terhadap Indeks Pembangunan Manusia (IPM). Penelitian ini diolah menggunakan regresi data panel dimana hasil penelitian ini mengungkapkan bahwa kemiskinan berpengaruh negatif, pertumbuhan ekonomi dan belanja modal berpengaruh positif. Penelitian kedua dilakukan oleh Ridwan Maulana dan Prasetyo Ari Bowo (2013) yang meneliti hubungan dan pengaruh pertumbuhan ekonomi, pendidikan dan teknologi terhadap indeks pembangunan manusia dengan menggunakan data panel. Hasil penelitian yang diperoleh menunjukkan bahwa pertumbuhan ekonomi dan pendidikan berpengaruh signifikan terhadap IPM.

Penelitian selanjutnya ditulis oleh Mita Pangestika dan Edy Widodo (2017) yang meneliti hubungan dan pengaruh PDRB, Tingkat Kemiskinan, pertumbuhan ekonomi, pendapatan asli daerah, dan belanja modal terhadap Indeks Pembangunan Manusia (IPM). Hasil dari penelitian ini menunjukkan bahwa PDRB mempunyai pengaruh positif dan signifikan terhadap IPM di D.I.Yogyakarta dan tingkat kemiskinan mempunyai pengaruh yang negatif dan signifikan terhadap IPM di D.I.Yogyakarta. Sedangkan variabel lainnya tidak berpengaruh terhadap IPM. Penelitian terakhir dilakukan oleh Dewi Azizah Meydiasari dan Ady Soetojo (2017) yang meneliti hubungan dan pengaruh distribusi pendapata, tingkat pengangguran, dan pengeluaran pemerintah terhadap IPM. Dengan menggunakan data panel, hasil dari penelitian ini distribusi pendapatan dan pengeluaran pemerintah berpengaruh positif tidak signifikan terhadap IPM. Sedangkan tingkat pengangguran berpengaruh negatif terhadap IPM.
Kerangka Pemikiran dan Hipotesis

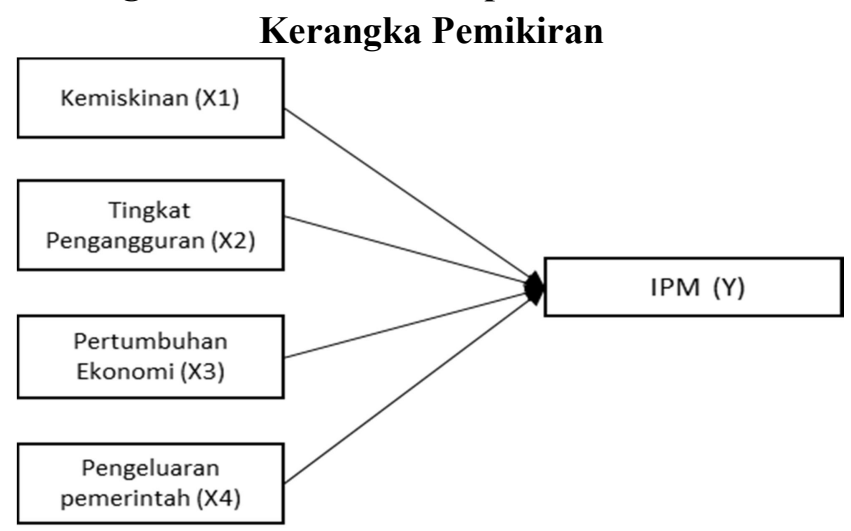

\section{Gambar 1}

Uji Hipotesis :

$\mathrm{H}_{0}: \beta_{\mathrm{k}}=0$ menunjukkan bahwa variable $\mathrm{x}$ tidak berpengaruh terhadap $\mathrm{Y}$

$\mathrm{H}_{1}: \beta_{\mathrm{k}} \neq 0$ menunjukkan bahwa variabel $\mathrm{x}$ berpengaruh terhadapa $\mathrm{Y}$

Keputusan : Tolak $\mathrm{H}_{0}$ pada tingkat signifikansi $\leq 5 \%$ Adapun hipotesis dalam penelitian ini adalah:

H1 : Terdapat pengaruh kemiskinan, tingkat pengangguran, pertumbuhan ekonomi, dan pengeluaran pemerintah terhadap IPM

$\mathrm{H} 2$ : Kemiskinan berpengaruh secara signifikan terhadap IPM

H3 : Tingkat Pengangguran berpengaruh secara signifikan terhadap IPM

H4 : Pertumbuhan Ekonomi berpengaruh secara signifikan terhadap IPM

H5 : Pengeluaran Pemerintah berpengaruh tidak signifikan terhadap IPM

\section{METODE PENELITIAN}

\section{Populasi dan Sampel Penelitian}

Populasi dan sampel pada penelitian ini adalah semua provinsi yang ada di Indonesia. Teknik pengambilan sampel pada penelitian ini adalah purposive sampling atau teknik penentuan sampel dengan pertimbangan tertentu. Kriteria pengambilan sampel pada penelitian ini adalah provinsi sudah terdaftar sebagai bagian negara Indonesia dan mempunyai publikasi laporan daerah yang di terbitkan oleh Badan Pusat Statistik (BPS) selama tahun penelitian yaitu 2014 - 2018. Hasil purposive sampling menunjukan 33 provinsi yang memenuhi kriteria sampel pada penelitian ini. Teknik pengumpulan data yang digunakan pada penelitian ini adalah melalui studi literatur dan dokumentasi. Studi literatur merupakan teknik pengumpuan data yang digunakan untuk mendapatkan informasi mengenai teori dan konsep yang berkaitan dengan 
permasalahan yang diteliti. Dokumentasi dalam penelitian ini digunakan untuk mendapatkan informasi atau data yang berkaitan dengan penelitian.

\section{Jenis Data}

Jenis data yang digunakan pada penelitian ini yaitu data sekunder yang terdiri dari data kemiskinan, pertumbuhan ekonomi, belanja daerah, tingkat pengangguran, pengeluaran pemerintah dan Indeks Pembangunan Manusia (IPM) 33 provinsi di Indonesia selama periode 2014-2019. Data diperoleh dari data yang telah di publikasikan pada beberapa sumber yaitu Badan Pusat Statistik dan website Kementerian Keuangan.

\section{Metode Analisis Data}

Metode analisis data yang digunakan pada penelitian ini menggunakan analisis regresi data panel. Data panel merupakan gabungan antara data lintas waktu (time series) dan lintas individu (cross section). Data times series pada penelitian ini adalah periode waktu penelitian yaitu 5 tahun (2014-2018) dan data cross section pada penelitian ini adalah laporan IPM setiap provinsi di Indonesia yang berjumlah 34 provinsi. Pada penelitian ini menggunakan aplikasi Eviews 9 dan menggunakan model pool dalam menganalisis data. Model pool sebenarnya merupakan data panel, kecuali masingmasing kelompok dipisahkan berasarkan objeknya (Winarno, 2015).

Persamaan model secara umum regresi data panel adalah sebagai berikut:

$\mathrm{Y}=\alpha \mathrm{i}+\beta 1 \mathrm{X} 1_{\mathrm{it}}+\beta 2 \mathrm{X} 2_{\mathrm{it}}+\beta 3 \mathrm{X} 3_{\mathrm{it}}+\beta 4 \mathrm{X} 4_{\mathrm{it}}+\mathrm{u}_{\mathrm{it}}$

Keterangan :

$\mathrm{Y}=$ Indeks Pembangunan Manusia (IPM)

$\mathrm{X} 1$ = Kemiskinan

$\mathrm{X} 2$ = Pengangguran

$\mathrm{X} 3=$ Pertumbuhan Ekonomi tingkat

$\mathrm{X} 4$ = Pengeluaran Pemerintah

\section{Menentukan metode estimasi model}

a. Common Effect Model

Common Effect Model (CEM) merupakan pendekatan yang mengasumsikan bahwa dari intersep daro semua objek cross section sama, dengan kata lain metode ini mengasumsikan tidak ada perbedaan setiap individu dalam berbagai kurun waktu (time invariant) (Gujarati, 2012).

b. Fixed Effect Model
Fixed Effect Model (FEM) merupakan pendekatakan yang mengasumsikan bahwa terdapat intersept antar individu tetapi koefisien (slope) dari variabel independen tetap sama antar individu atau antar waktu (Gujarati, 2012). Pada FEM setiap individu cross section memiliki nilai intersept masing-masing.

c. Random Effect Model

Random Effect Model (REM) akan mengestimasi data panel dimana variabel gangguan mungkin saling berhubungan antar waktu dan antar individu. Model ini juga disebut dengan Error Component Model (ECM) atau teknik Generalized Least Square (GLS) (Basuki \& Yuliadi, 2015).

\section{Pemilihan Model Estimasi}

a. Uji Chow

Uji chow dilakukan untuk memilih apakah pedekatan CEM atau FEM yang lebih baik digunakan untuk regresi data panel. Hipotesis dalam uji chow adalah sebagai berikut (Basuki \& Prawoto, 2016):

$\mathrm{H}_{0}$ : nilai prob cross section $\mathrm{F}>\alpha(0,05), \mathrm{CEM}$

$\mathrm{H}_{1}$ : nilai prob cross section $\mathrm{F}<\alpha(0,05)$, FEM

b. Uji Hausman

Uji hausman dilakukan untuk memilih apakah pendekatan FEM atau REM yag lebih baik digunakan untuk regresi data panel. Hipotesis dalam uji hausman adalah sebagai berikut (Basuki \& Prawoto, 2016):

$\mathrm{H}_{0}$ : nilai prob Chi-Square $>\alpha(0,05)$, REM

$\mathrm{H}_{1}$ : nilai prob Chi-Square $<\alpha(0,05)$, FEM

c. Uji Lagrange Multiplier

Uji Lagrange Multiplier dilakukan untuk memilih apakah pendekatan CEM atau REM yang lebih baik digunakan untuk regresi data panel. Hipotesis dalam uji lagrange multiplier adalah sebagai berikut (Basuki \& Prawoto, 2016) :

$\mathrm{H}_{0}$ : nilai prob Breusch-Pagan $>\alpha(0,05)$, CEM.

$\mathrm{H}_{1}$ : nilai prob Breusch-Pagan $<\alpha(0,05)$, REM.

\section{Uji Asumsi Klasik}

Tidak semua uji asumsi klasik harus dilakukan pada setiap model regresi linear dengan pendekatan Ordinary Least Square (OLS) (Basuki, Regresi Model PAM, ECM, dan Data Panel dengan Eviews 7, 2014). Uji linearitas tidak digunakan karena sudah diasumsikan bahwa model bersifat linear. Uji normalitas pada dasarnya tidak merupakan syarat 
Best Linear Unbias Estmator (BLUE) dan beberapa pendapat tidak mengharuskan. Uji autokorelasi hanya terjadi pada time series, tidak pada data panel dan cross section. Uji multikolinearitas perlu dilakukan pada regresi yang menggunakan lebih dari satu variabel bebas karena uji tersebut bertujuan untuk menguji apakah dalam model regresi ditemukan adanya korelasi yang tinggi atau sempurna antar variabel independen (Ghazali, 2013). Uji heteroskedatisitas biasanya terjadi pada data cross section, data panel lebih dekat ke ciri cross section dibandingkan time series. Uji heteroskedatisitas digunakan untuk menguji apakah dalam model regresi terjadi ketidaksamaan variance dari residual satu pengamatan ke pengamatan yang lain (Ghazali, 2013). Berdasarkan uraian tersebut maka pada penelitian ini hanya menguji uji multikolinearitas dan uji heteroskedatisitas.

\section{Uji Hipotesis}

a. Uji t ( Parsial)

Uji statistik $t$ pada dasarnya menunjukan seberapa jauh pengaruh satu variabel independen terhadap variabel dependen dengan menganggap variabel independen lainnya konstan (Ghazali, 2013). Pengujian dapat dilakukan dengan membandingkan prob $\mathrm{t}$ hitung dengan tingkat kesalahan alpha $(0,05)$. Apabila nilai prob $\mathrm{t}$ hitung lebih kecil dari 0,05 maka dapat disimpulkan bahwa variabel bebas berpengaruh signifikan terhadap variabel terikat, sedangkan apabila nilai prob t hitung lebih besar dari 0,05 maka dapat disimpulkan bahwa variabel bebas tidak berpengaruh signifikan terhadap variabel terikat.

b. Uji F (Simultan)

Uji Statistik F pada dasarnya menunjukan apakah semua variabel independen yang dimasukan dalam model mempunyai pengaruh secara bersama-sama atau simultan terhadap variabel dependen (Ghazali, 2013). Pengujian dapat dilakukan dengan membandingkan nilai prob $\mathrm{F}$ hitung dengan tingkat kesalahan alpha $(0,05)$. Apabila nilai prob $\mathrm{F}$ hitung lebih kecil dari 0,05 maka dapat disimpulkan bahwa model regresi diestimasi layak, sedangkan apabila nilai prob $\mathrm{F}$ hitung lebih besar dari 0,05 maka dapat disimpulkan bahwa model regresi diestimasi tidak layak. c. Koefisien Determinasi $\left(\mathrm{R}^{2}\right)$

Koefisien determinasi bertujuan untuk mengukur seberapa jauh kemampuan model dalam menerangkan variasi variabel independen dalam penelitian. Nilai koefisien determinan yang mendekati 1 berarti variabel-variabel independen hampir memberikan informasi yang dijelaskan untuk memprediksi variabel-variabel dependen (Widarjono, 2013).

\section{HASIL DAN PEMBAHSAN}

\subsection{Hasil penelitian}

\section{Pemilihan Model Estimasi}

Pengujian estimasi model dilakukan untuk mencari model yang paling tepat untuk digunakan dalam analisis regresi data panel. Pengujian estimasi model dilakukan dengan tiga cara yaitu uji chow, uni hausman dan uji LM. Uji chow digunakan untuk memilih CEM atau FEM yang lebih baik digunakan pada penelitian.

\section{Tabel 1}

\section{Uji Chow}

\begin{tabular}{|c|c|c|c|}
\hline Effects Test & Statistic & d.f. & Prob. \\
\hline $\begin{array}{l}\text { Cross-section F } \\
\text { Cross-section }\end{array}$ & 15.917015 & $(32,127)$ & 0.0000 \\
\hline Chi-square & 264.294685 & 32 & 0.0000 \\
\hline
\end{tabular}

Sumber: Data diolah dengan Eviews 9, 2020

Tabel diatas menunjukan bahwa nilai prob cross section $\mathrm{F}<\alpha(0,05)$ maka $\mathrm{H}_{0}$ ditolak dan FEM lebih tepat digunakan dalam mengestimasi data panel dari pada CEM. Selanjutnya uji hausman yang digunakan untuk memilih apakah pendekatan FEM atau REM yag lebih baik digunakan untuk regresi data panel.

Tabel 2

\section{Uji Hausman}

\begin{tabular}{cccc}
\hline \hline $\begin{array}{c}\text { Test } \\
\text { Summary }\end{array}$ & $\begin{array}{c}\text { Chi-Sg. } \\
\text { Statistic }\end{array}$ & $\begin{array}{c}\text { Chi-Sq. } \\
\text { d.f. }\end{array}$ & Prob. \\
\hline \hline $\begin{array}{c}\text { Cross-section } \\
\text { random }\end{array}$ & $\begin{array}{c}509.34447 \\
4\end{array}$ & 4 & 0.0000 \\
\hline \hline
\end{tabular}

Sumber: Data diolah dengan Eviews 9, 2020

Tabel diatas menunjukan bahwa nilai prob ChiSquare $<\alpha(0,05)$ maka $\mathrm{H}_{0}$ ditolak dan FEM lebih tepat digunakan dalam mengestimasi data panel dari pada REM. Dari hasil uji chow dan hausman dapat disimpulkan bahwa FEM lebih tepat digunakan dari pada CEM dan REM maka uji Lagrange Multiplier (LM) tidak dilanjutkan dan penelitian ini menggunakan FEM. 
Tabel 3

Fixed Effect Model

\begin{tabular}{crrrr}
\hline \hline Variable & Coefficient & Std. Error & t-Statistic & Prob. \\
\hline \hline C & 1968.959 & 3.067328 & 641.9134 & 0.0000 \\
X1? & 0.860328 & 0.046523 & 18.49257 & 0.0000 \\
X2? & -1.090509 & 0.051466 & -21.18895 & 0.0000 \\
X3? & -0.049605 & 0.086460 & -0.573732 & 0.5672 \\
X4? & 0.042709 & 0.029916 & 1.427607 & 0.1559 \\
\hline \hline $\begin{array}{l}\text { R-squared } \\
\text { Adjusted R- }\end{array}$ & 0.807855 & Mean dependent var & 2016.000 \\
squared & 0.753389 & S.D. dependent var & 1.422863 \\
S.E. of & 0.706593 & Akaike info criterion & 2.338817 \\
regression & 63.40779 & Schwarz criterion & 3.038177 \\
$\begin{array}{l}\text { Sum squared } \\
\text { resid }\end{array}$ & -154.7830 & Hannan-Quinn criter. & 2.622731 \\
Log likelihood & 14.83222 & Durbin-Watson stat & 1.349567 \\
F-statistic & 0.000000 & & \\
Prob(F-statistic) & & & \\
\hline \hline
\end{tabular}

Sumber: Data diolah dengan Eviews 9, 2020

Persamaan model secara umum regresi data panel adalah sebagai berikut:

$\mathrm{Y}=1968.959+0.860 \mathrm{X} 1_{\mathrm{it}}-1.090 \mathrm{X} 2_{\mathrm{it}}-0.049 \mathrm{X} 3_{\text {it }}$ $+0.042 \mathrm{X}_{\mathrm{it}}+\mathrm{u}_{\mathrm{it}}$

Keterangan :

$\mathrm{Y}=$ Indeks Pembangunan Manusia (IPM)

$\mathrm{X} 1=$ Kemiskinan

$\mathrm{X} 2$ = Pengangguran

$\mathrm{X} 3$ = Pertumbuhan Ekonomi

$\mathrm{X} 4$ = Pengeluaran Pemerintah

Selain itu hasil regresi pada data panel dengan menggunakan metode pool data dengan model fixed effect menampilkan persamaan untuk mengetahui nilai intersep setiap provinsi yang menjadi sampel. Hasil penelitian tersebut menunjukan bahwa provinsi Papua mempunyai konstanta yang paling tinggi yaitu 27.61585 dan Jakarta mempunyai konstanta yang paling rendah yaitu -17.16834 .

\section{Uji Asumsi Klasik}

\section{a. Uji Multikolinearitas}

Metode yang digunakan untuk melihat ada tidaknya multikolinearitas dalam penelitian ini adalah dengan menggunakan auxiliary. Apabila terdapat persamaan dengan beberapa variabel independen, maka harus menjalankan regresi sebanyak jumlah variabel independen dengan masing-masing analisis menggunakan variabel independen sebagai variabel dependen (Winarno, 2015).

Tabel 4

Hasil Uji Multikolinearitas

\begin{tabular}{|l|l|}
\hline Model persamaan & R-Square \\
\hline $\mathrm{Y}$ & 0.807 \\
\hline $\mathrm{X} 1$ & 0.949 \\
\hline $\mathrm{X} 2$ & 0.966 \\
\hline $\mathrm{X} 3$ & 0.892 \\
\hline $\mathrm{X} 4$ & 0.448 \\
\hline
\end{tabular}

Sumber: Data diolah dengan Eviews 9, 2020
Apabila R-Square variabel $\mathrm{Y}$ lebih besar dibanding dengan R-Square variabel independen pada regresi auxiliary maka dikatakan bahwa dalam model ini tidak ditemukan adanya multikoliniearitas (Basuki \& Yuliadi, 2015). Dari hasil tabel diatas dapat disimpulkan bahwa tidak semua variabel independen terbebas dari multikolinearitas. Multikolinearitas dapat dilihat dari $\mathrm{R}^{2}$ dan signifikansi dari variabel yang digunakan, jika $R^{2}$ tinggi sementara banyak atau semua variabel tidak signifikan maka diduga terjadi multikolinearitas (Gujarati, 2012). Pada penelitian ini, hasil $\mathrm{R}^{2}$ sebesar $80,7 \%$ dan dua variabel signifikan sehingga model ini dianggap terbebas dari multikolinearitas.

b. Uji Heteroskedastisitas

Untuk melihat apakah terdapat heteroskedastisitas pada penelitian ini menggunakan metode Weighted Least Square (WLS). Metode WLS dapat digunakan jika varian dan residual diketahui (Winarno, 2015).

Tabel 5

Uji Heteroskedastisitas

Weighted Statistics

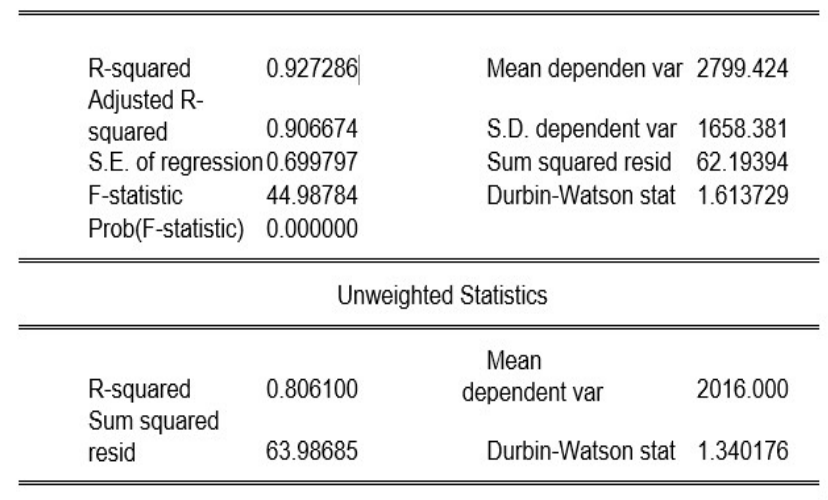

Sumber: Data diolah dengan Eviews 9, 2020

Apabila nilai sum square resid pada fixed effect unweight lebih besar daripada nilai sum square resid pada fixed effect weight dan nilai R-square pada fixed effect weight lebih besar dibandingkan dengan nilai $\mathrm{R}$-square pada fixed effect unweight. Dari hasil tabel di atas maka dapat disimpulkan bahwa dalam model tidak terjadi heteroskedastisitas atau bersifat homokedastisitas.

\section{Uji Hipotesis}

a. Uji t (Parsial)

- Hasil regresi data panel fixed effect pada tabel fixed effect model menunjukan variabel kemiskinan mempunyai nilai probabilitas sebesar 0.0000 lebih kecil dari nilai 0.05. Maka dapat disimpulkan bahwa variabel kemiskinan 
berpengaruh signifikan terhadap Indeks Pembangunan Manusia (IPM) 33 provinsi di Indonesia selama periode 2014-2019.

- Hasil regresi data panel fixed effect pada tabel fixed effect model menunjukan variabel tingkat pengangguran mempunyai nilai probabilitas sebesar 0.0000 lebih kecil dari nilai 0.05. Maka dapat disimpulkan bahwa variabel tingkat pengangguran berpengaruh signifikan terhadap Indeks Pembangunan Manusia (IPM) 33 provinsi di Indonesia selama periode 20142019.

- Hasil regresi data panel fixed effect pada tabel fixed effect model menunjukan variabel pertumbuhan ekonomi mempunyai nilai probabilitas sebesar 0.5672 lebih besar dari nilai 0.05 . Maka dapat disimpulkan bahwa variabel pertumbuhan ekonomi berpengaruh tidak signifikan terhadap Indeks Pembangunan Manusia (IPM) 33 provinsi di Indonesia selama periode 2014-2019.

- Hasil regresi data panel fixed effect pada tabel fixed effect model menunjukan variabel pengeluaran pemerintah mempunyai nilai probabilitas sebesar 0.1559 lebih besar dari nilai 0.05 . Maka dapat disimpulkan bahwa variabel pengeluaran pemerintah berpengaruh tidak signifikan terhadap Indeks Pembangunan Manusia (IPM) 33 provinsi di Indonesia selama periode 2014-2019.

\section{b. Uji F (Simultan)}

Hasil regresi data panel fixed effect pada tabel fixed effect model menunjukan nilai probbabilitas Fstatistic sebesar 0.000000 lebih kecil dari nilai alpha (0.05). Hasil tersebut memberikan kesimpulan bahwa variabel independen yaitu variabel kemiskinan, tingkat pengangguran, pertumbuhan ekonomi, pengeluaran pemerintah secara bersama-sama berpengaruh signifikan terhadap variabel independen IPM.

\section{c. Koefisien Determinasi $\left(\mathrm{R}^{2}\right)$}

Hasil regresi data panel fixed effect pada tabel fixed effect model menunjukan nilai $\mathrm{R}^{2}$ sebesar $80.78 \%$ menunjukan bahwa variabel kemiskinan, tingkat pengangguran, pertumbuhan ekonomi, pengeluaran pemerintah dapat menjelaskan variabel Y, sisanya $19.22 \%$ dijelaskan oleh variabel lain di luar variabel penelitian.

\subsection{Pembahasan}

Berdasarkan hasil pengolahan data diatas, maka dapat dilihat secara bersama-sama variabel independen yaitu variabel kemiskinan, tingkat pengangguran, pertumbuhan ekonomi, pengeluaran pemerintah berpengaruh signifikan terhadap variabel independen IPM. Akan tetapi, secara parsial tidak semua variabel independen berpengaruh terhadap variabel dependen.

Variabel independen pertama yang diuji secara parsial yaitu variabel kemiskinan. Hasil dari uji yang dilakukan menunjukkan bahwa kemiskinan memiliki pengaruh secara signifikan terhadap Indeks Pembangunan Manusia. Hasil ini sesuai dengan hipotesis penelitian bahwa kemiskinan berpengaruh terhadap Indeks Pembangunan Manusia (IPM). Hasil penelitian ini juga sejalan dengan hasil penelitian sebelumnya yang dilakukan oleh Mirza (2012) yang menunjukkan bahwa kemiskinan memiliki pengaruh signifikan terhadap peningkatan maupun penurunan pada Indeks Pembangunan Manusia. Hasil ini juga sejalan dengan penelian Pangestika dan Widodo (2017) bahwa kemiskinan memiliki pengaruh terhadap Indeks Pembangunan Manusia. Variabel kedua adalah pengangguran. Hasil dari pengujian menunjukkan bahwa tingkat pengangguran berpengaruh secara signifikan terhadap peningkatan maupun penurunan Indeks Pembangunan Manusia (IPM). Hasil penelitian ini sejalan dengan penelitian yang dilakukan dengan Meydiasari (2017) dan Baeti (2013) dimana pengangguran berpengaruh signifikan terhadap variabel IPM. Menurutnya jumlah pengangguran yang tinggi akan mengurangi kemakmuran hidup masyarakat melalui berkurangnya pendapatan masyarakat yang menjadi faktor dominan dalam peningkatan pembangunan manusia. Hal ini berakibat masyarakat yang tidak mempunyai pendapatan tidak bisa memenuhi kebutuhan hidupnya dan memperbaiki kualitas manusia seperti membayar biaya pendidikan dan kesehatan.

Hal ini sesuai dengan ajaran islam bahwa kemisikinan dapat mempengaruhi sumber daya manusia karena masyarakat yang miskin tidak akan memikirkan pendidikan dan kesehatan karena yang dipikirkan hanya bagaimana memenuhi kebutuhan sehari-hari. Ketika manusia tidak memikirkan pendidikan, maka di masa depan taraf hidup nya akan sama seperti sekarang dan akan menyebabkan pengangguran meningkat. Hal ini juga akan dapat berpengaruh terhadap ketersediaanya sumber daya 
manusia yang berkualitas untuk memajukan bangsa dan negara. Islam mendorong umatnya untuk bekerja dan memproduksi, karena Allah SWT akan memberi balasan yang setimpal sesuai dengan amal/ kerja maupun usaha yang dilakukannya. Hal ini sesuai dengan Al-Qur'an surat An-Nahl ayat 97 yang berbunyi :

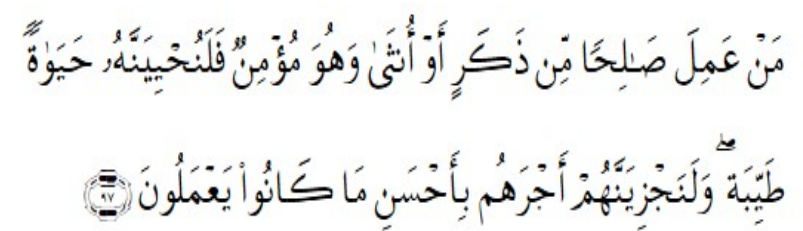

Artinya:

Barangsiapa yang mengerjakan amal saleh, baik laki-laki maupun perempuan dalam Keadaan beriman, Maka Sesungguhnya akan Kami berikan kepadanya kehidupan yang baikdan Sesungguhnya akan Kami beri Balasan kepada mereka dengan pahala yang lebih baik dari apa yang telah mereka kerjakan (QS. An-Nahl : 97)

Ayat ini menjelaskan bahwa jika kita ingin memenuhi kecukupan dalam hidup maka kita harus berusaha dan bekerja keras. Allah akan memberi amalan yang baik jika umatnya mau bekerja keras dengan cara yang halal dan baik sesuai dengan ajaranya. Dengan demikian kerja keras merupakan hal utama dalam mencapai suatu kesejahteraan, yang dalam penelitian ini kesejahteraan diukur melalui Indeks Pembangunan Manusia (IPM).

Variabel independen pertumbuhan ekonomi dan pengeluaran pemerintah pada penelitian ini berpengaruh tidak signifikan terhadap variabel Indeks Pembangunan Manusia (IPM). Hal ini bertentangan dengan hasil penelitian sebelumnya yang dilakukan oleh Pangestika dan Widodo (2017). Pertumbuhan ekonomi yang berpengaruh tidak signifikan terhadap IPM menunjukkan bahwa pertumbuhan ekonomi belum mencapai seluruh sektor, khusunya sektor pendidikan dan kesehatan dimana menurut UNDP kedua sektor ini penting dalam pembangunan manusia sehingga pertumbuhan ekonomi tidak dapat mempengaruhi peningkatan pada Indeks Pembangunan Manusia di Indonesia (IPM). Hal ini sejalan dengan penelitian Rahayu (2019) dimana pertumbuhan ekonomi tidak selalu menjamin dapat meningkatkan kesejahteraan karena menurut Mahsury pertumbuhan ekonomi menurut islam bersifat multi dimensi yang mencakup aspek kuantitatif dan kualitatif. Tujuanya bukan sematamata kesejahteraan material dunia, tetapi juga kesajahteraan akhirat seperti yang dijelaskan dalam Al-Qur'an Surat An-Nisaa (4) ayat 9 :

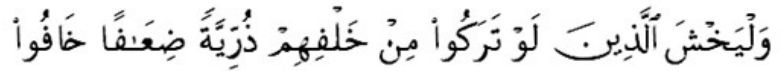

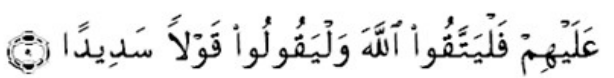

Artinya :

Dan hendaklah takut kepada Allah orang-orang yang seandainya meninggalkan dibelakang mereka anakanak yang lemah, yang mereka khawatir terhadap (kesejahteraan) mereka. oleh sebab itu hendaklah mereka bertakwa kepada Allah dan hendaklah mereka mengucapkan perkataan yang benar (QS. An-Nisa (4): 9)

Ayat ini mejelaskan bahwa manusia harus memikirkan kesejahteraannya baik di dunia maupun di akhirat, dimana untuk mencapai kehidupan yang sejahtera di dunia maupun di akhirat adalah dengan bertakwa kepada Allah SWT.

Variabel pengeluaran pemerintah yang merupakan variabel independen terakhir juga tidak berpengaruh secara signifikan terhadap Indeks Pembangunan Manusia (IPM). Hasil penelitian ini sejalan dengan penelitian sebelumnya yang dilakukan oleh Meydiasari (2017) bahwa pengeluaran pemerintah berpengaruh positif dan tidak signifikan terhadap Indeks Pembangunan Manusia (IPM). Hal ini menunjukkan bahwa pengeluaran pemerintah secara keseluruhan belum menjangakau sektor-sektor seperti kesehatan dan pendidikan yang mana smenjadi sektor penting dalam pembangunan manusia. Pada akhirnya, seluruh variabel yang diteliti pada penelitian dapat saling mepengaruhi satu sama lain, untuk memastikannya dapat dilakukan uji pada penelitian selanjutnya. Karena, menurut Oluwatobi (2011) pada kondisi jangka panjang, pertumbuhan ekonomi suatu negara tergantung modal pembangunan manusia dan diperlukan adanya penyaluran belanja modal negara pada sektor pendidikan dan kesehatan guna meningkatkan modal pembangunan manusia dan berakhir pada peningkatan pertumbuhan ekonomi suatu negara.

\section{KESIMPULAN}

Berdasarkan hasil penelitian maka dapat disimpulkan bahwa kemiskinan dan tingkat pengangguran memiliki pengaruh signifikan terhadap IPM tahun penelitian. Kemiskinan dan pengangguran mempunyai kaitan yang erat satu sama lain. Jumlah pengangguran yang tinggi akan mengurangi 
kemakmuran hidup masyarakat melalui berkurangnya pendapatan masyarakat yang akan mempunyai kecenderungan untuk meningkatnya kemiskinan. Hal ini sesuai dengan ajaran islam bahwa kemisikinan dapat mempengaruhi sumber daya manusia karena masyarakat yang miskin tidak akan memikirkan pendidikan dan kesehatan karena yang dipikirkan hanya bagaimana memenuhi kebutuhan sehari-hari. Ketika manusia tidak memikirkan pendidikan, maka di masa depan taraf hidup nya akan sama seperti sekarang dan akan menyebabkan pengangguran meningkat. Sedangkan variabel lain pada penelitian ini yaitu pertumbuhan ekonomi dan pengeluaran pemerinta berpengaruh tidak signifikan terhadap IPM pada tahun penelitian. Pertumbuhan ekonomi yang berpengaruh tidak signifikan terhadap IPM menunjukkan bahwa pertumbuhan ekonomi belum mencapai seluruh sektor. Hal tersebut juga terjadi pada pengeluaran pemerintah secara keseluruhan belum menjangakau sektor-sektor penting seperti kesehatan dan pendidikan yang mana menjadi sektor penting dalam pembangunan manusia. Pertumbuhan ekonomi dan pengeluaran pemerintah mempunyai hubungan sebab akibat yang sangat erat. Pertumbuhan ekonomi menurut islam bersifat multi dimensi yang mencakup aspek kuantitatif dan kualitatif yang bukan semata-mata hanya kesejahteraan material dunia, tetapi juga kesajahteraan akhirat. Kesejahteraan tersebut dapat dilihat dengan alokasi pengeluaran pemerintah untuk memakmurkan rakyat dalam suatu negara. Pemerintah sebagai regulator harus bijak dalam mengambil keutusan-keputusan yang mendukung kepentingan rakyat secara menyeluruh agar tercipta masyarakat yang sejahtera.

\section{DAFTAR PUSTAKA}

Baeti, N. (2013). Pengaruh Pengangguran, Pertumbuhan Ekonomi, Dan Pengeluaran Pemerintah Terhadap Pembangunan Manusia Kabupaten/Kota Di Provinsi Jawa Tengah Tahun 2007-2011. Economics Development Analysis Journal.

Basuki, A. T. (2014). Regresi Model PAM, ECM, dan Data Panel dengan Eviews 7. Yogyakarta: Katalog Dalam Terbitan (KTD).

Basuki, A. T., \& Prawoto, N. (2016). Analisis Regresi dalam Penelitian Ekonomi \& Bisnis: Dilengkapi Aplikasi SPSS \& Eviews. Depok: PT Rajagrafindo Persada.
Basuki, A. T., \& Yuliadi, I. (2015). Ekonometrika : Teori dan Aplikasi. Yogyakarta: Mitra Pustaka Matani.

BPS. (2016). Statistik Indonesia 2016.

BPS. (2017). Statistik Indonesia 2017.

BPS. (2017). Statistik Keuangan Pemerintah Provinsi 2014-2017.

BPS. (2018). Indeks Pembangunan Manusia 2018. BPS. Retrieved from https://www.bps.go.id: https://www.bps.go.id

BPS. (2018). Stastistika Indonesia 2018.

BPS. (2018). Statistik Keuangan Pemerintah 2018.

Christy, F. A., \& Adi, H. P. (2013). Analisa Pengaruh

Belanja Modal Pemerintah Daerah, Tenaga Kerja Terserap dan Indeks Pembangunan Manusia Terhadap Pertumbuhan Ekonomi dan Kemiskinan (Studi Kasus 35 Kabupaten/Kota di Provinsi Jawa Tengah. Jurnal Bisnis dan Ekonomi (JBE) Universitas Diponegoro.

Ghazali, I. (2013). Aplikasi Analisis Multivariate dengan SPSS 21 Update PLS Regresi

Semarang: Badan Penelitian Universitas Diponegoro.

Gujarati, N. D. (2012). Dasar-Dasar Ekonometrika (Vol. Vol 5). (R. C. Mangunsong, Trans.) Jakarta: Salemba.

Huda, N., \& dkk. (2012). Keuangan Publik Islami Pendekatan Teoritis dan Sejarah. Jakarta: Kencana Prenada Media Group.

Mangkoesoebroto, G. (1993). Ekonomi Politik. Yogyakarta: BPFE.

Mankiw, N. G. (2003). Makro Ekonomi. Terjemahan: Fitria Liza. Jakarta: Penerbit Erlangga.

Masriah, \& Mujahid. (2011). Pembangunan Ekonomi Berwawasan Lingkungan. Malang: Penerbit Universitas Negeri Malang.

Maulana, R., \& Bowo, P. A. (2013). Pengaruh Pertumbuhan Ekonomi, Pendidikan Dan Teknologi Terhadap Ipm Provinsi Di Indonesia 2007-2011. Jejak, Journal Economics and Policy.

Meydiasari, D. A., \& Soejoto, P. A. (2017). Analisis Pengaruh Distribusi Pendapatan, Tingkat Pengangguran, Dan Pengeluaran Pemerintah Sektor Pendidikan Terhadap IPM. Jurnal Pendidikan Ekonomi Manajemen Dan Keuangan Vol. 01 No. 02 November 2017. 
Mirza, D. S. (2012). Pengaruh Kemiskinan, Pertumbuhan Ekonomi, Dan Belanja Modal Terhadap Indeks Pembangunan Manusia Di Jawa Tengah Tahun 2006-2009. Economics Development Analysis Journal.

Nurwati, N. (2008). Kemiskinan : Model Pengukuran, Permasalahan, dan Alternatif Kebijakan. Jurnal Kependudukan Padjadjaran, Vol. 10, No. 1, Januari 2008: 1 - 11.

Oluwatobi, S., \& Oluranti, O. (2011). Government Expenditure on Human Capital Development: Implications for Economic Growth in Nigeria. Journal of Sustainable Development, Vol.4 No 3.

Pangestika, M., \& Widodo, E. (2017). Analisis Regresi Panel terhadap Faktor-Faktor yang Mempengaruhi Indeks Pembangunan Manusia di Kabupaten/Kota D.I.Yogyakarta. Seminar Nasional dan The 4th Call for Syariah Paper.

Prastyo, A. A. (2010). Analisis Faktor-Faktor yang Mempengaruhi Tingkat Kemiskinan. Semarang: Undip Press.

Prihastuti, A. H. (2018). Pengaruh Alokasi Belanja Modal Dan Pertumbuhan Ekonomi. Menara Ekonomi, ISSN : 2407-8565; E-ISSN: 25795295 .
Rahayu, N. A. (2019). Pengaruh Kemiskinan dan Pertumbuhan Ekonomi terhadap Indeks Pembangunan Manusia dalam Perspektif Ekonomi Islam di Kabupaten Lampung Tengah Tahun 2010-2017.

Sukirno, S. (2000). Makro Ekonomi Modern, Perkembangan Pemikiran dari Klasik Hingga Keynesian Baru. Jakarta: PT. Raja Grafindo Persada.

Suradi. (2007). Pembangunan Manusia, Kemiskinan dan Kesejahteraan Sosial. Jurnal Penelitian dan Pengembangan Kesejahteraan Sosial, vol 12, no 03.

Vildzah, N., \& Muhammad, S. (2016). Faktor-Faktor Yang Mempengaruhi Indeks Pembangunan Manusia. Jurnal Ilmiah Mahasiswa (JIM) Ekonomi Pembangunan Fakultas Ekonomi dan Bisnis Unsyiah Vol.1 No.2 November 2016 : 429-437.

Widarjono, A. (2013). Ekonometrika Pengantar dan Aplikasi Eviews . Yogyakarta: UPP STIMYKPN.

Winarno, W. (2015). Analisis Ekonometrika dan Statistika dengan Eviews. Yogyakarta: UPP STIM YKPN. 